\title{
Zero liquid discharge treatment systems: prerequisite to industries
}

\begin{abstract}
Industrialization is necessary for country's economic growth. Increase in industrial development has elevated water consumption and is resulting in depletion of water resources. On the other hand, water pollution is a major issue. People have long been trying to find cost effective and reliable ways to treat wastewater and recycle or reusing the treated water has become a necessity. Zero Liquid Discharge (ZLD) is an ideal situation of complete closed loop cycle, where discharge of any liquid effluent is eliminated; it is a remarkable effort of every industry who implements it to meet with the environmental regulation in a challenging way. However, it is facing some challenges for its implementation including its high costs and energy efficiency. Here in this review, we have presented various ZLD technologies which are feasible for different industrial sectors and some innovative technologies by which the precious water can be saved and recycled at source.
\end{abstract}

Keywords: zero liquid discharge, pharmaceuticals, textiles, fertilizers, ZLD technologies
Volume 5 Issue I - 2020

\author{
Ashok Kumar Rathoure \\ Department of Environment, Independent Researcher, India
}

Correspondence: Dr Ashok Kumar Rathoure, Department of Environment, Independent Researcher India, Flat \#107, Akshar Park-A, Near Dhara Complex, Behind Atopnagar Bhatar Road, Surat (Gujarat), India, Tel 945050 I47I,

Email asokumr@gmail.com

Received: October 08, 2019 | Published: January 20, 2020
Abbreviations: ZLD, zero liquid discharge; MBR, membrane bio-reactor technology; ATFD, agitated thin film dryer; TDS, total dissolved solids; BOD, biochemical oxygen demand; $\mathrm{CPCB}$, central pollution control board; MD, membrane distillation; SHFCC, solid hollow fiber cooling crystallization; ZLDD, zero liquid discharge desalination; MD-C, membrane distillation-crystallization; FD, freeze desalination

\section{Introduction}

Booming megatrends in industrialisation and urbanization are creating higher stress on the environment, including the world's freshwater resources. In many areas, globally and particularly in fast-developing and emerging economies like India, rapid growth in industries and manufacturing units are creating a threat to water quality and tremendous strain on water supplies. Concerns related to water availability risks are increased in regions prone to water scarcity.

As these trends intensify, industries that use large amounts of water and generate high quantum of wastewater are under growing pressure to implement more sustainable water management strategies which uses less amount of water, minimise impacts to receiving waters and mitigate operational risks. This results in driving developments in technologies in the global water treatment market. ${ }^{1}$

ZLD systems are getting greater attention as useful wastewater treatment/water management solutions for complex industrial wastewaters. It is a water treatment process in which wastewater is treated, purified and further recycled. The ZLD process completely eliminates liquid discharge from industry thus reduces and eliminates possibility of pollution discharge concerns and regulatory disposal norms. ${ }^{2}$

An efficiently designed ZLD (Zero Liquid Discharge) System is used for minimising the quantum of wastewater requiring treatment and also to produce a stream of water suitable for reuse in processing plants. ${ }^{3}$ A general approach for ZLD is to increase concentrationof wastewater and further crystallize to a solid.

\section{Background}

ZLD technology was initially developed for power plants, in USA and later implemented globally. During early seventies, high salinity of the River Colorado due to discharge from power plants, developed the need for imposing Zero Liquid Discharge. Regulators were primarily concerned with discharge from scrubbers and cooling tower blow downs in power plants.

First ZLD installed was of $114-454 \mathrm{~m}^{3} /$ hour units, based on evaporation/crystallization. Initially low-cost ponds were used for evaporation of Reverse Osmosis (RO) reject. In Germany, ZLD systems for coal-fired power plants were a result of strict regulations and laws in the 1980s. ${ }^{4}$

Annually, worldwide investment of around 200 million USD is represented by construction of zero liquid discharge plants. Currently, there are many concentrator/evaporator systems in numerous industries round the globe. It is spreading widely to water scarce regions and to highly sensitive and polluted environments. ${ }^{4}$

Countries like China and India, where water scarcity exists and recycle/reuse of industrial water is less (i.e. water recovery ratio is less), probably require to develop solutions for ZLD systems. The ZLD market is likely to see further increase in activity based on increased water scarcity and pressure from the regulators.

\section{India}

All textile units were required to install ZLD systems which were producing wastewater effluent greater than $25 \mathrm{kLD}$ as issued in draft policy by the Government in 2015. As stated by Vishnu et al., ${ }^{5}$ ZLD systems were already implemented by 29 dyeing industries in the Tirupur city of Tamil Nadu by 2008, where not only water was recovered but also salts were recovered which were directly used in 
dyeing processes. Conferring to a current technical report, the market for ZLD in India was approximated to around39 million USD in 2012 and was projected to continuously increase from 2012 to 2017 at a rate around $7 \%$. In this market, the power, petrochemical, textile and brewing and distillery industries are the key application areas. ${ }^{6}$

Legislation related to ZLD in India as given by $\mathrm{Saha}^{7}$ :

a. Supreme Court directed polluting pharmaceutical industries near Hyderabad to pay farmers Rs 4000/acre annually (between 1992-2002) due to loss of soil fertility.

b. Tamil Nadu High Court Order mandated ZLD for dyeing, bleaching units, tanneries and distilleries. (2006)

c. Andhra Pradesh High Court order mandated ZLD for 12 large Pharmaceutical units around Hyderabad discharging 25,000 kLD. (2008)

d. Tamil Nadu Government and Central Government Scheme for a subsidy of Rs. 320 crore (interest free loan) to set up ZLDs in the state following the court order of 2006. (2010)

e. Punjab Pollution Control Board mandated ZLD in 8 large electroplating industries in Ludhiana (2010).

f. Punjab Pollution Control Board assisted 500+ small electroplating units in Ludhiana to set up a CETP with ZLD. (2010)

g. Rajasthan Government declared a Capital Subsidy on ZLD based ETP equal to $20 \%$ of amount paid to the trader for the treatment plant excluding civil works, subjected to a maximum of Rs. 1.0 Crore (2014).

\section{ZLD system}

It is a system consisting of unit processes or unit operations or their combination, such that there is no discharge of liquid effluent from an industry, process plant, project etc. It indicates there is no liquid discharge since the effluent is effectively treated, recycled and reused. Zero liquid discharge is generally accomplished by concentrating the wastewater utilizing numerous technologies together with membranebased and multi effect evaporation-based systems. ${ }^{8}$ ZLD comprises of:

A. Eliminating of wastewater effluent stream from the industry,

B. Recycling of treated water and

C. Establishing negligible liquid pollutants norm.

Generally, the incentives behind implementation of ZLD vary depending on terrestrial location and application. United States, China, and India form majority of markets for ZLD with highest economy and largest populations to be served.

\section{ZLD technologies}

Main aim of ZLD is to recover useful products and salts from rejects, apart from recovery of maximum water for recycle. Major ZLD Technologies are as follows:

i. Solvent extraction/Stripper

ii. Membrane Bio-Reactor Technology (MBR)

iii. Ultra-filtration/Reverse Osmosis

iv. Evaporation Technologies

v. Agitated Thin Film Dryer (ATFD)

vi. Incinerator

As per Gujarat Pollution Control Board, India (2016), ZLD technologies, their respective uses, advantages, disadvantages and application are given in Table 1 .

Table I ZLD technologies

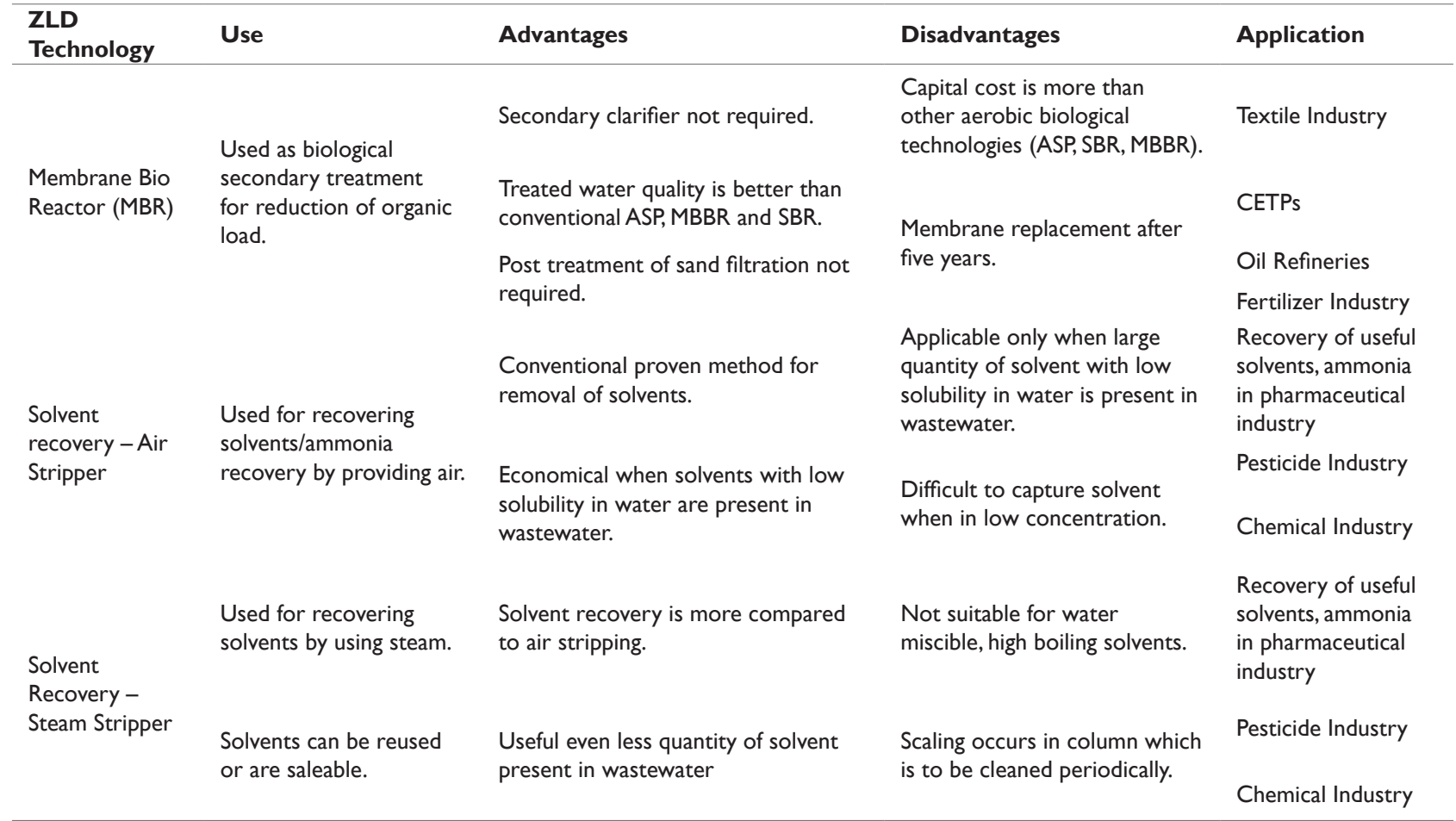


Table continue

\begin{tabular}{|c|c|c|c|c|}
\hline $\begin{array}{l}\text { ZLD } \\
\text { Technology }\end{array}$ & Use & Advantages & Disadvantages & Application \\
\hline $\begin{array}{l}\text { Ultra Filtration } \\
\text { (UF) }\end{array}$ & $\begin{array}{l}\text { Used for removal of } \\
\text { colloidal matter and } \\
\text { bacteria and viruses. } \\
\text { Used as pre-treatment } \\
\text { to RO. }\end{array}$ & $\begin{array}{l}\text { Removes suspended, colloidal } \\
\text { particles, bacteria, viruses. }\end{array}$ & $\begin{array}{l}\text { Does not filter dissolved solids, } \\
\text { gases and organics. Frequent } \\
\text { backwash, membrane cleaning. } \\
\text { Replacement of membranes } \\
\text { after } 5 \text { years required. }\end{array}$ & $\begin{array}{l}\text { Pre-treatment } \\
\text { to } R O \text { in all ZLD } \\
\text { plants. }\end{array}$ \\
\hline $\begin{array}{l}\text { Reverse } \\
\text { Osmosis (RO) }\end{array}$ & $\begin{array}{l}\text { Used for removal of } \\
\text { salinity (TDS) and } \\
\text { residual organics by } \\
\text { passing wastewater } \\
\text { through semi-permeable } \\
\text { membrane by applying } \\
\text { high pressure. }\end{array}$ & $\begin{array}{l}\text { Most effective treatment for removal } \\
\text { of salinity (TDS) with more than } 99 \% \\
\text { salt rejection. } \\
\text { Clean technology and no handling } \\
\text { of chemicals like acid/alkali like ion } \\
\text { exchange technology. }\end{array}$ & $\begin{array}{l}\text { Membrane replacement } \\
\text { required after application of } \\
3 \text { years. } \\
\text { Cleaning of membrane } \\
\text { frequently due to membrane } \\
\text { fouling } \\
\text { Reject Water }\end{array}$ & $\begin{array}{l}\text { Used in all industrial } \\
\text { sectors for TDS } \\
\text { removal and } \\
\text { recycling the water. }\end{array}$ \\
\hline $\begin{array}{l}\text { Multiple Effect } \\
\text { Evaporator } \\
\text { (MEE) }\end{array}$ & $\begin{array}{l}\text { Used to evaporate } \\
\text { wastewater to separate } \\
\text { water and salt by } \\
\text { using heat of steam in } \\
\text { sequence of vessels. }\end{array}$ & $\begin{array}{l}\text { Proven method for recovery of water } \\
\text { from saline water and separation of } \\
\text { salt. }\end{array}$ & $\begin{array}{l}\text { Very high operating cost due } \\
\text { to steam requirement. }\end{array}$ & $\begin{array}{l}\text { Pharmaceutical } \\
\text { Industry, Textile } \\
\text { Industry, Pesticide } \\
\text { Industry, Dyes and } \\
\text { Dye Intermediates, } \\
\text { Steel Industry, } \\
\text { Fertilizer Industry }\end{array}$ \\
\hline $\begin{array}{l}\text { Mechanical } \\
\text { Vacuum } \\
\text { Compressor } \\
\text { (MVR) }\end{array}$ & $\begin{array}{l}\text { Water vapour generated } \\
\text { in the evaporator is } \\
\text { compressed to higher } \\
\text { pressure which acts } \\
\text { as heat source for } \\
\text { evaporation. }\end{array}$ & $\begin{array}{l}\text { Useful when steam not available. } \\
\text { Low operating cost. }\end{array}$ & $\begin{array}{l}\text { Suitable only for liquid with } \\
\text { narrow boiling point rise } \\
\text { (BPR). }\end{array}$ & Textile Industry \\
\hline Crystallizer & $\begin{array}{l}\text { Used to dry high TDS } \\
\text { water or products using } \\
\text { heat. }\end{array}$ & $\begin{array}{l}\text { Used for recovery of salts like Sodium } \\
\text { Sulphate, Sodium Chloride, Sodium } \\
\text { Thiosulphate, Zinc Sulphate etc. } \\
\text { Simple Evaporation method of single } \\
\text { effect evaporation. }\end{array}$ & $\begin{array}{l}\text { Scaling and corrosion of unit is } \\
\text { a problem. }\end{array}$ & $\begin{array}{l}\text { All industrial } \\
\text { sectors. }\end{array}$ \\
\hline $\begin{array}{l}\text { Agitated Thin } \\
\text { Film Dryer } \\
\text { (ATFD) }\end{array}$ & $\begin{array}{l}\text { Used to dry high TDS } \\
\text { water or products using } \\
\text { fast revolving rotor in a } \\
\text { heating jacket. }\end{array}$ & $\begin{array}{l}\text { Gentle evaporation and high } \\
\text { evaporation rate. } \\
\text { Continuous cleaning of heating } \\
\text { surface. } \\
\text { One passes Evaporation. }\end{array}$ & $\begin{array}{l}\text { Scaling and corrosion of unit is } \\
\text { a problem. }\end{array}$ & $\begin{array}{l}\text { Textile Industry } \\
\text { Pharmaceutical } \\
\text { Industry for final } \\
\text { drying before } \\
\text { disposal. }\end{array}$ \\
\hline \multirow{3}{*}{ Incinerator } & \multirow{3}{*}{$\begin{array}{l}\text { Used for burning the } \\
\text { concentrated effluent by } \\
\text { thermal energy }\end{array}$} & \multirow{3}{*}{$\begin{array}{l}\text { Useful method for very high strength } \\
\text { (High COD) effluent which is difficult } \\
\text { to biodegrade. No further treatment } \\
\text { is required. }\end{array}$} & Requires very high energy. & $\begin{array}{l}\text { Pharmaceutical } \\
\text { Industry }\end{array}$ \\
\hline & & & $\begin{array}{l}\text { Operational cost is high. } \\
\text { Capital cost is high. }\end{array}$ & $\begin{array}{l}\text { Dye and Dye } \\
\text { Intermediates } \\
\text { Pesticide Industry }\end{array}$ \\
\hline & & & $\begin{array}{l}\text { Viable for only small quantities } \\
\text { of effluent. }\end{array}$ & \\
\hline
\end{tabular}




\section{Major factors}

Major factors for adopting ZLD technologies by industries are as given below 6 :

a. Stricter regulations for wastewater disposal.

b. High cost of installation of ZLD system is outweighed by high cost of wastewater disposal along with costly non-compliance penalties.

c. Due to intensifying scarcity of water globally, recovery of water to larger extents through ZLD is being enhanced.

d. Water from conventional sources is expensive whereas use of recycled water would be relatively cheap.

e. Awareness for environmental problems resulting from growth of education and social responsibility.

f. ZLD system, irrespective of high cost, may be economical solution for minimizing cost in transportation of waste in large quantities for longer distance.

\section{Accurate analysis of generated effluent}

For efficient working of ZLD system, it is necessary to obtain accurate analysis of effluents generated from industries. Some of the major parameters to be determined as per Ahirrao ${ }^{8}$ are given below:

a) TDS (Total Dissolved Solids): This parameter governs the salt handling capacity and evaporation duty.

b) Organic Matter: This parameter helps to indicate the purity of contained salt, BOD (Biochemical Oxygen Demand) and COD (Chemical Oxygen Demand) of process condensate, and the organic cut from evaporation.

c) Compositional Analysis: This parameter helps to determine the composition of pure salt and mixed salt, the process schematics, and various other operating parameters.

d) Characteristics at Various Concentrations: The characteristics of feed effluent determine process schematics and types of evaporators to be used.

e) Solvents: Solvents may be removed by solvent stripper in case low boilers are present in the feed effluent, since low boilers may interfere with evaporation and thus the efficiency of the overall system.

\section{Benefits}

i. Installation of ZLD technology encourages water usage monitoring closely, avoid wastage and recycling of water by conventional and relatively less expensive solutions, therefore being useful for a unit's water management system.

ii. $90-95 \%$ recovery of water and valuable salts from the wastewater justifies its high operational cost.

iii. Meeting most stringent regulatory norms leads the industry to a more sustainable growth.

iv. Using zero liquid discharge techniques, there is a possibility to recover water from sewage for municipal and industrial use.

v. Water demand from industry reduces freeing up water to meet the demands for domestic use and agriculture efficiently. vi. Ecology of water bodies, soil salinity and groundwater nearby discharging units are not affected.

vii. Recovery and reuse of treated water results in management of water resources and its conservation.

\section{Challenges}

There are several challenges being faced for development and implementation of ZLD. Some of these ${ }^{9}$ include:

a. Development of high and effective recovery system to recover greater than $95 \%$ of wastewater

b. Outcomes of ZLD include challenges for disposal since high amounts of hazardous solid wastes are generated leading to think for ZWD (Zero Waste Disposal) Plants.

c. Technology shortcomings.

d. Increased operational cost and finances on the plant and its global, national \& regional competitiveness.

e. High carbon foot print.

f. Selection the suitable techniques according to quantum of effluent and its characteristics.

Therefore, techno-economic contemplations are necessary for developing a zero liquid discharge approach.

\section{Drawbacks}

The most noteworthy drawbacks of ZLD systems include

i. Increase in both, capital and operation and maintenance cost.

ii. Difference in design of ZLD System based on different industrial units.

iii. Complications in dealing with complex streams of wastewater.

iv. Usage of high quantity of chemicals in treatment of wastewater.

v. Intensive consumption of energy.

vi. Huge quantity of sludge (both hazardous and other solid waste) is generated.

vii. ZLD implementation increases the cost of processing in industries by $25-30 \%$.

\section{Sector-wise concept of ZLD and treatment options}

As per Central Pollution Control Board (CPCB), ${ }^{10}$ New Delhi (2015), sector-wise treatment options for industries is given in Table 2. The sector wise options shows that the specific industry need to installed ZLD system as per their waste-water characteristics and their use. Here in India, the CPCB has advised to install the ZLD system to all industries and made it mandatory to reuse the water after treatment.

\section{Membrane distillation (MD) and solid hollow fiber cooling crystallization}

A novel hybrid system of integrating membrane distillation (MD) and solid hollow fiber cooling crystallization (SHFCC) has been successfully developed for simultaneous production of fresh water and inorganic salt crystals from $\mathrm{NaCl}$ brine solutions. Porous PVDF hollow fibre membranes consisting of PTFE particles are spun for the MD subsystem, while non-porous PVDF hollow fibres are fabricated 
as heat exchangers for the SHFCC subsystem. To optimize the operation parameters, the Taguchi's method is utilized for experiment design including three key factors; namely, feed temperature $\left(\mathrm{T}_{\mathrm{f}}\right)$, distillate amount $\left(\mathrm{W}_{\mathrm{d}}\right)$ and water amount to wash away the scallant $\left(\mathrm{W}_{\mathrm{w}}\right)$. As per researcher, the best combined parameters to maximize the crystal harvested at $\mathrm{W}_{\mathrm{d}}=14 \mathrm{~g}$ and $\mathrm{T}_{\mathrm{f}}=50^{\circ} \mathrm{C}$. Narrowly distributed $\mathrm{NaCl}$ crystals with a small mean size of $35-45 \mu \mathrm{m}$ are successfully generated by the hybrid system, and a relatively long-term MDSHFCC operation of 15 cycles is conducted to verify the system stability and feasibility by Luo et al., ${ }^{11}$

Table 2 Sector-wise treatment options for industries

\begin{tabular}{|c|c|c|c|}
\hline S. No. & Sector & Treatment options & Remarks \\
\hline \multirow{5}{*}{ I } & & $\begin{array}{l}\text { I. Bio-methanation followed by RO/MEE followed by } \\
\text { incineration (slop fired). }\end{array}$ & \\
\hline & & $\begin{array}{l}\text { 2. Bio-methanation followed by RO/MEE followed by } \\
\text { drying (spray/rotary). }\end{array}$ & \\
\hline & Distillery & & ZLD Achievable \\
\hline & & $\begin{array}{l}\text { 3. Concentration through MEE followed by } \\
\text { coprocessing in cement/thermal power plant. }\end{array}$ & \\
\hline & & $\begin{array}{l}\text { 4. Bio-methanation and RO followed by MEE followed } \\
\text { by bio-composting. }\end{array}$ & \\
\hline \multirow{3}{*}{2} & & $\begin{array}{l}\text { Primary treatment }+ \text { secondary treatment+ pre- } \\
\text { treatment for RO + Reverse Osmosis + MEE }\end{array}$ & \\
\hline & Tannery & & ZLD Achievable \\
\hline & & $\begin{array}{l}\text { (recovery of permeate, crystallised salt, reuse of the } \\
\text { recovered condensate) }\end{array}$ & \\
\hline \multirow[t]{3}{*}{3} & Pulp \& Paper & $\begin{array}{l}\text { Primary treatment + Degasification }+ \text { RO, } 2 \text { stage }+ \\
N F \text { and UF + Evaporator, Concentrator/Crystallizer }\end{array}$ & Black Liquor totally to be ZLD in any plant. \\
\hline & & $\begin{array}{l}\text { Restricting effluent generation to } 100 \text { Litres/ton cane } \\
\text { crushed. }\end{array}$ & \\
\hline & & $\begin{array}{l}\text { Water consumption to be restricted to } 100 \text { Litres/ton } \\
\text { initially and further to } 50 \text { Litres/ton cane crushed. }\end{array}$ & \\
\hline \multirow[t]{4}{*}{4} & Sugar & $\begin{array}{l}\text { Condensate polishing unit mandatory Recycle of } \\
\text { excess condensate to process or ancillary units. }\end{array}$ & $\begin{array}{l}\text { Water conservation \& irrigation protocol } \\
\text { as alternate to ZLD }\end{array}$ \\
\hline & & $\begin{array}{l}\text { Water management/audit to reduce spray pond/ } \\
\text { cooling tower blow downs and excess condensate. }\end{array}$ & \\
\hline & & Irrigation protocol for disposal into land applications & \\
\hline & & $\begin{array}{l}\text { High COD, Low TDS Effluent treatment system } \\
\text { Primary treatment+ Secondary treatment + tertiary } \\
\text { chemical treatment to reduce TDS (Pressure sand } \\
\text { filter, Activated Carbon filter and filter press for } \\
\text { dewatering of sludge). RO system (permeate is } \\
\text { utilized as cooling tower makeup water) + Multi effect } \\
\text { evaporator/incinerators. }\end{array}$ & \\
\hline \multirow[t]{2}{*}{5} & Pharmaceuticals & & ZLD Achievable \\
\hline & & $\begin{array}{l}\text { High COD, High TDS Effluent treatment } \\
\text { system } \\
\text { Primary treatment + stripper to remove VOC }+3 \\
\text { stages Multi Effect Evaporator (forced circulation) } \\
\text { Agitator Thin Film Drier (ATFD)+(MEE condensate is } \\
\text { being taken along with Low TDS effluent for further } \\
\text { treatment)+ MEE/incineration. }\end{array}$ & \\
\hline
\end{tabular}




\begin{tabular}{|c|c|c|c|}
\hline S. No. & Sector & Treatment options & Remarks \\
\hline \multirow{3}{*}{6} & \multirow{3}{*}{ Textiles } & $\begin{array}{l}\text { I. Ozonation }+ \text { bio-oxidation }+ \text { sand filtration }+ \\
\text { activated carbon adsorption }+ \text { micro filtration }+ \\
\text { reverse osmosis }(3 \text { stage })+\text { multiple effect evaporator }\end{array}$ & \multirow{3}{*}{ ZLD Achievable } \\
\hline & & $\begin{array}{l}\text { 2. Chemical precipitation + bio-oxidation + chemical } \\
\text { precipitation + sand filtration + Activated carbon } \\
\text { adsorption + micron filtration + reverse osmosis }(3 \\
\text { stages) + multiple effect evaporator }\end{array}$ & \\
\hline & & $\begin{array}{l}\text { 3. Chemical precipitation }+ \text { bio-oxidation }+ \text { sand } \\
\text { filtration }+ \text { dual media filtration }+ \text { micron filtration } \\
+ \text { reverse osmosis }(3 \text { stages })+\text { multiple effect } \\
\text { evaporators }\end{array}$ & \\
\hline 7 & Refineries & $\begin{array}{l}\text { API, primary treatment, secondary treatment and } \\
\text { tertiary treatment. The tertiary treatment is mainly } \\
\text { Reverse Osmosis and permeate is utilized and rejects } \\
\text { are discharged into cooling tower }\end{array}$ & Water conservation, Reuse \& partial ZLD \\
\hline 8 & Fertilizer & $\begin{array}{l}\text { Chemical treatment+ Reverse Osmosis (Rejects as } \\
\text { filler material and permeate in the process) }\end{array}$ & Water conservation, Reuse \& partial ZLD \\
\hline 9 & $\begin{array}{l}\text { Dye \& Dye } \\
\text { Intermediates }\end{array}$ & Chemical Treatment+ MEE & ZLD Achievable \\
\hline
\end{tabular}

\section{Zero liquid discharge desalination}

Zero liquid discharge desalination (ZLDD) is a sustainable solution to the global water scarcity problem. It provides high water recovery, zero waste generation and valuable salt production. Lu et al., ${ }^{12}$ have developed a mathematical model of a novel ZLDD system that consists of freeze desalination (FD) and membrane distillationcrystallization (MD-C) also developed based on the theories of heat and mass transfer as well as experimental results. To improve the energy efficiency of the system, effects of important parameters, such as the feed temperature, concentration, and distillate temperature of MD and the recovery ratio of FD on system operating curves and energy consumptions have been systematically investigated with the aid of mathematical modelling. For a lab-scale hybrid ZLDD system operating at optimized conditions with a daily seawater processing capacity of $72 \mathrm{~kg}, 50 \%$ of its heating energy can be supported by a $50.5 \mathrm{~m}^{2}$ solar panel and its cooling energy can be $100 \%$ provided by re-gasification of $207-\mathrm{kg}$ liquefied natural gas. ${ }^{12}$ Figure 1 has presented how the desalination works and sea water converted into pure potable water.

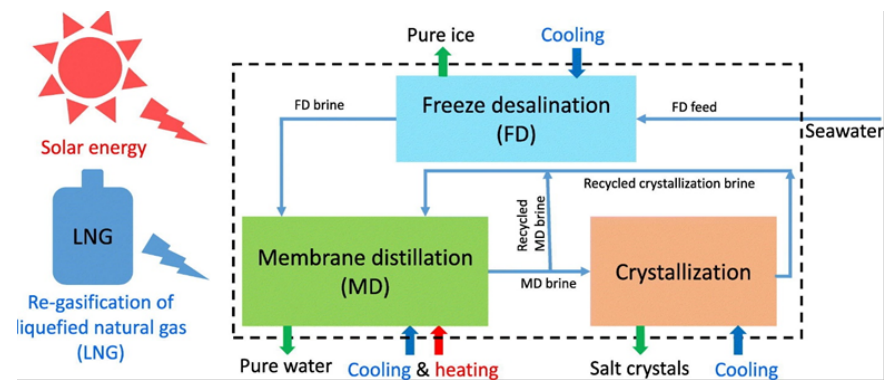

Figure I Zero liquid discharge desalination. ${ }^{12}$

\section{Case study}

\section{Ammonia manufacturing industry}

Wastewater generation from a typical ammonia manufacturing industry is given in Table 3. Typical water balance diagram of an ammonia manufacturing plant is given in Figure 2. All the wastewater generated from industry is recycled/reused in the plant itself. Therefore, it works on the ZLD concept i.e. no effluent goes out of the industrial premises. Sewage to be generated during construction as well as operation phase from construction labour and additional technical staff will be treated in existing facility. Effluent from proposed expansion plant in form of condensate will be sent to Phosphoric Acid plant for reuse in process. No additional effluent will be sent out of company premises. All the effluent water from process shall be reused and utilized fully in the phosphoric acid plant for processing. No water from process shall be discharged outside the manufacturing unit hence it will be a ZERO effluent discharge unit (Figure 2).

\section{Pharmaceutical industry}

Water balance diagram and flow diagram of ETP of a typical pharmaceutical industry is depicted in Figure 3 and Figure 4 respectively. Effluent generation from industrial activities is 110.8 KLD. Total effluent generation from the industry is segregated into high COD/TDS and low COD/TDS concentration streams. High concentrated wastewater stream from manufacturing process is treated in stripper followed by Multiple Effect Evaporator. Treated water from stripper along with WTP reject is sent to MEE. Condensate water from MEE is sent to ETP along with other low COD/TDS waste streams i.e. cooling, washing and boiler. After treatment in ETP followed by RO, permeate from RO is reused for cooling and reject is sent to MEE. Hence, there is no discharge of treated effluent from the industry and unit maintains Zero Liquid Discharge. 


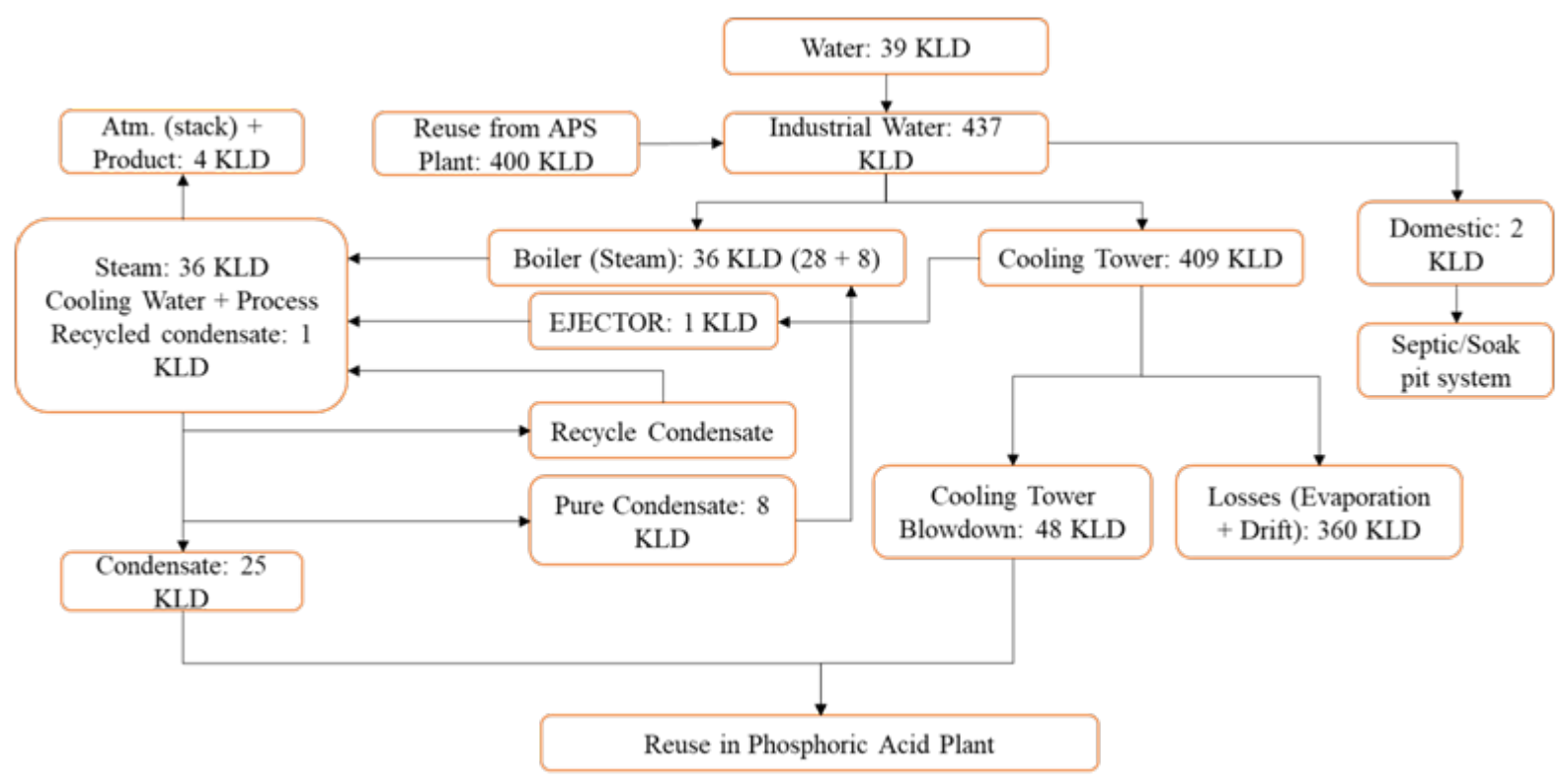

Figure 2 Water balance diagram of a typical ammonia manufacturing plant.

Table 3 Wastewater generation from ammonia manufacturing plant

\begin{tabular}{llll} 
S. No. & Activity & Wastewater generation (KLD) & Treatment/remarks \\
\hline I & Domestic & 2 & Treated in existing septic tank/soak pit.
\end{tabular}

Industrial

Steam Condensate/

Process Condensate

2

Cooling Tower
Blowdown

Net Total
312 KLD with in proposed plant (AS-I) will be recycled in process and balance 25 KLD will be sent to Phosphoric Acid plant for reuse. Hence, complete recycle in plant process.

Sent to Phosphoric Acid plant. For reuse in dust suppression/process hence, complete recycle in plant process.

No additional effluent is sent out of company premises.

Figure 3 Water balance diagram of a typical pharmaceutical industry.

\section{Textile processing cluster}

The quantity of wastewater generation from a typical textile processing cluster depends upon the quantity of water used for various purposes. Water balance, flow diagram of CETP and flow diagram of common sewage treatment plant of a typical textile processing cluster are depicted in Figures 5-7 respectively. The effluent generated is treated in the CETP and reused for textile process. Wastewater generated from the domestic activities is treated in common sewage treatment plant and treated water is utilized for toilet flushing and greenbelt maintenance. Therefore, no wastewater is discharged outside the cluster premises and the proposed project is operated on zero discharge condition. The blow down water from the boiler is treated in the RO system followed by deaerator. The condensate return after the evaporation and steam loss is recycled for boiler make-up, until there is any source of contamination or dissolved solids contained within the system. Hence, industry can achieve the ZERO liquid discharge system. The most important factor is to check the output parameters before using this water into any process. As per the ZLD systems installed in various industries in Gujarat, they are using the waste water after treatment into the process and other miscellaneous uses like drum and reactor washing, floor washing, dust suppression, green belt watering, etc. ${ }^{13}$ 


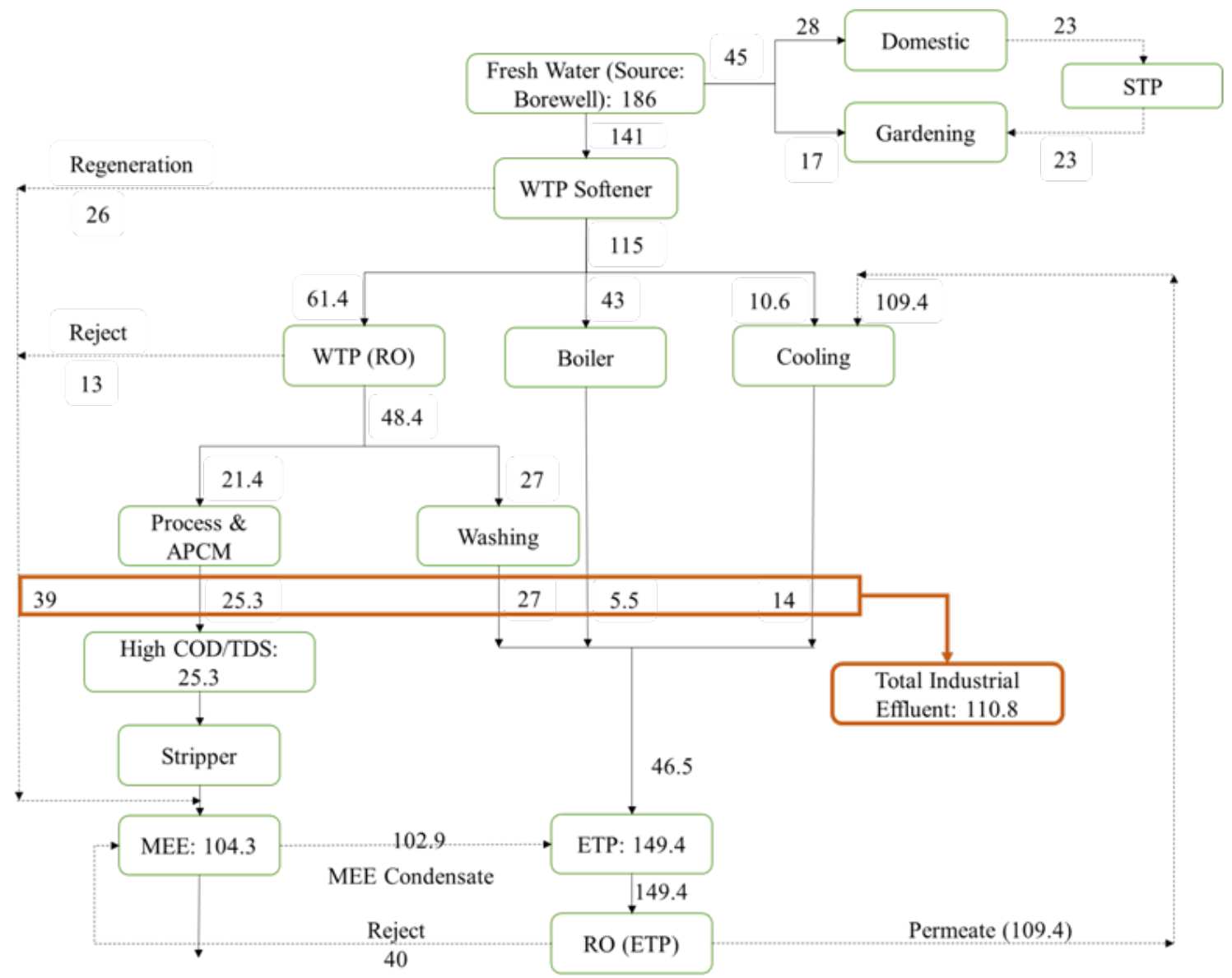

Figure 3 Water balance diagram of a typical pharmaceutical industry.

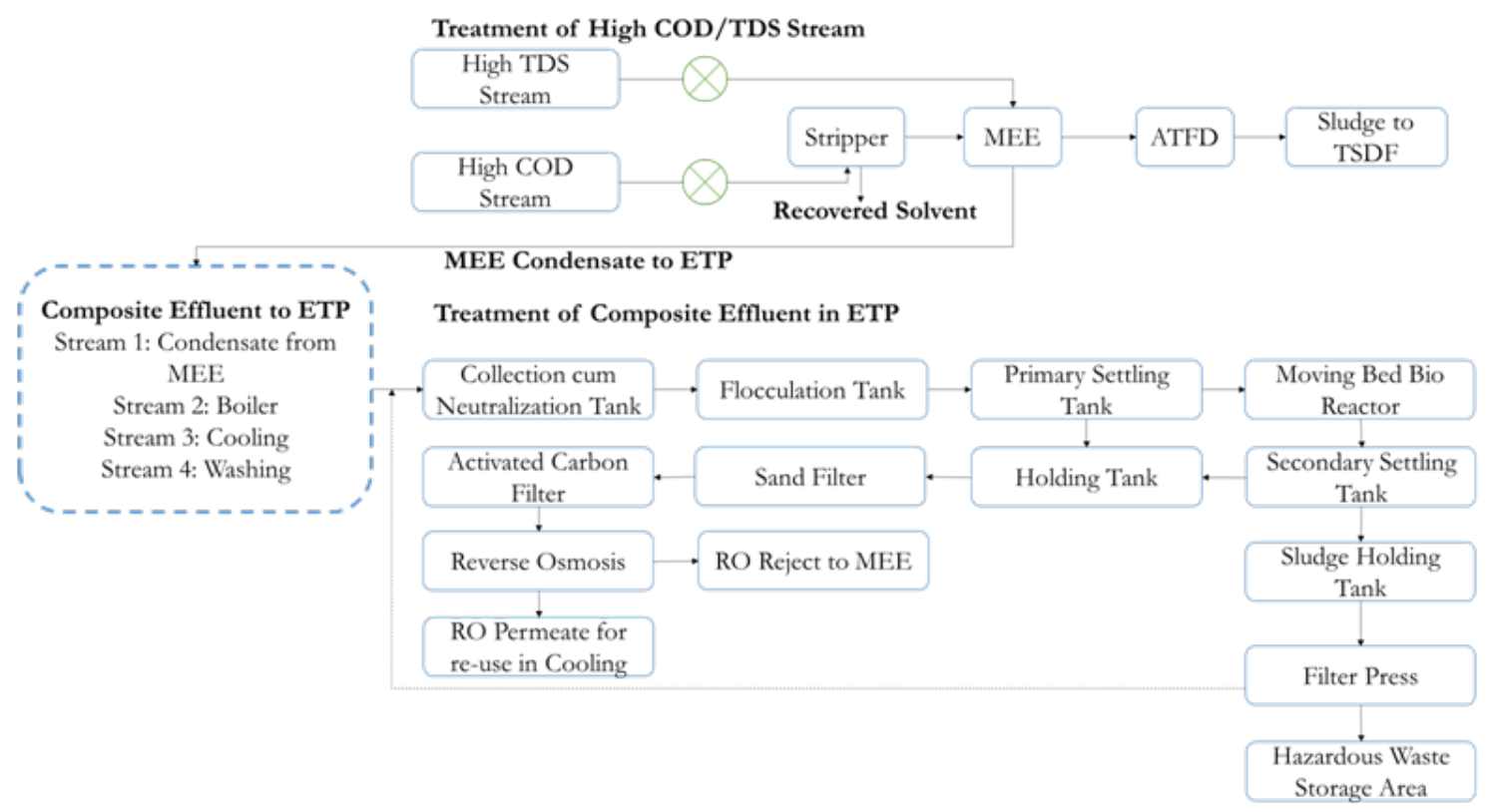

Figure 4 ETP of a typical pharmaceutical industry. 


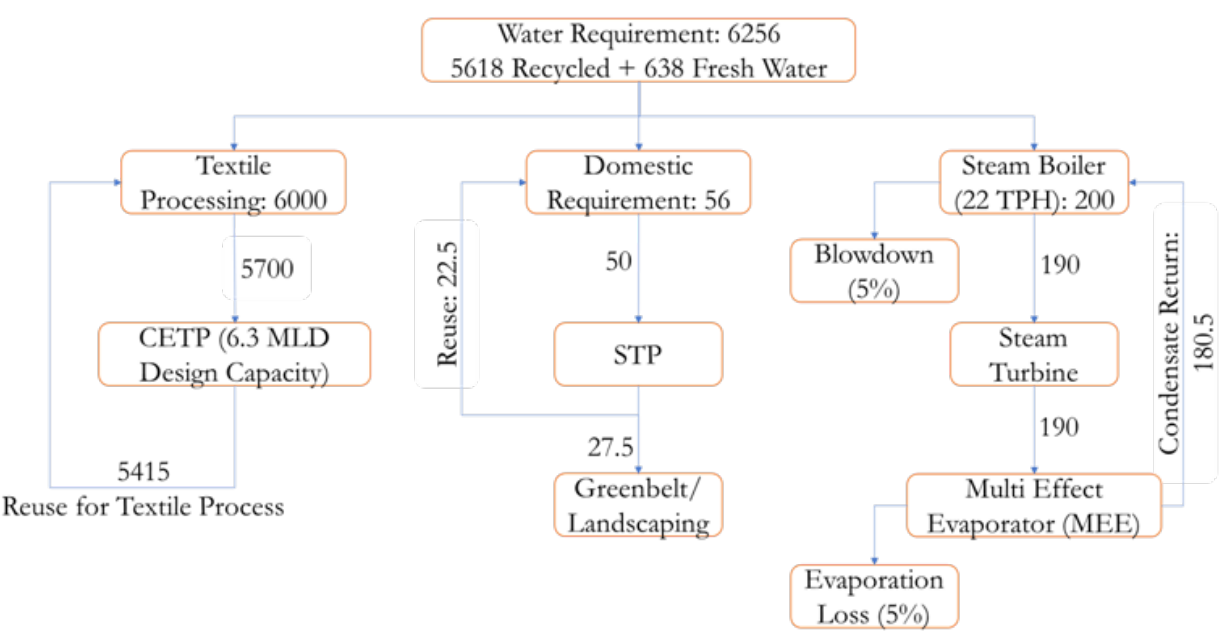

Figure $\mathbf{5}$ Water balance diagram of a typical textile processing cluster.

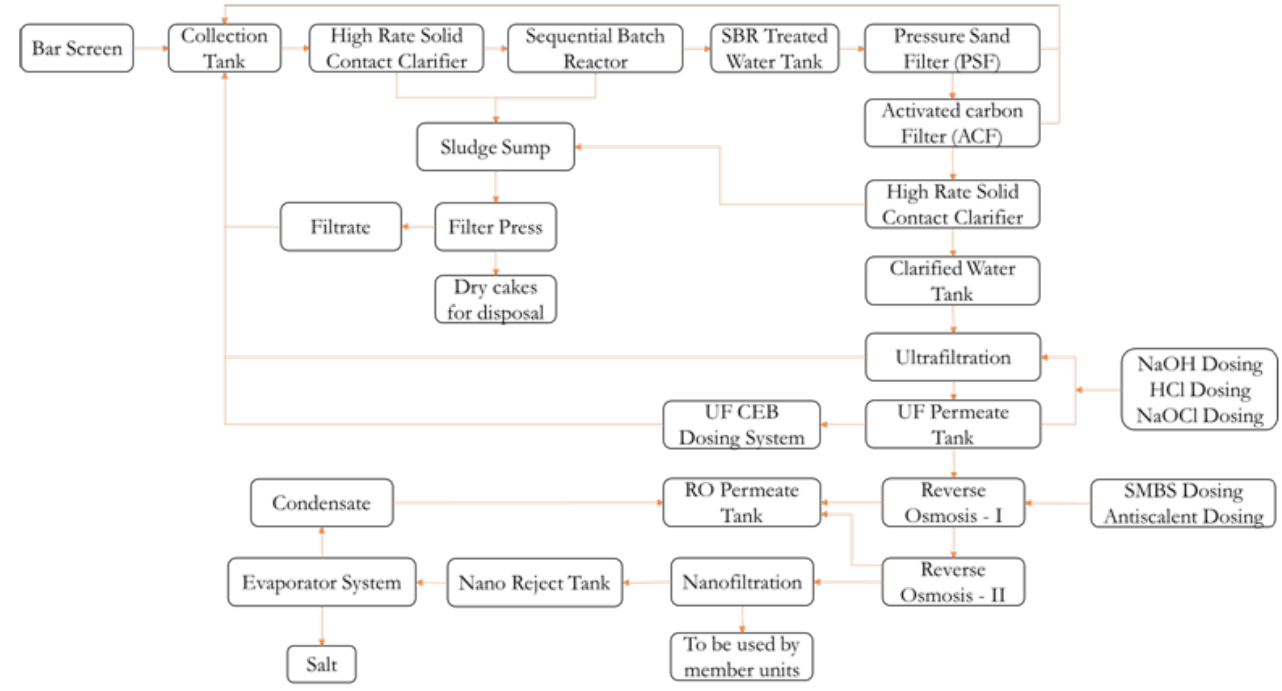

Figure 6 Flow diagram of CETP.

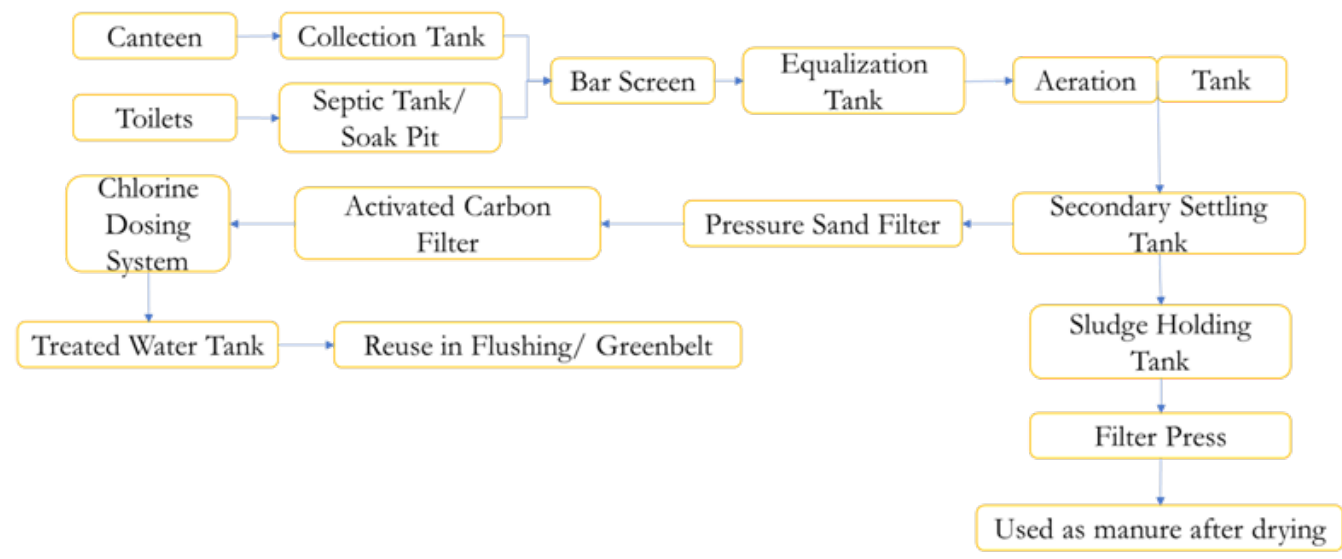

Figure 7 Flow diagram of common sewage treatment plant. 


\section{Conclusion}

The concerns over the environmental impact of water pollution have increased, and also ground water resources are gradually being depleted. In the current situation, it is required to recycle the wastewater generated from industrial outlets. On other hand, environmental authorities are being directed to establish "Zero Liquid Discharge (ZLD) plants" in all industrial sectors. Hence, for waste minimization, resource recovery, toxic industrial wastewater treatment and mitigation of potential impacts on water quality of receiving streams, ZLD (Zero-Liquid Discharge) is being thought of an evolving technology. Reduction in water pollution and augmentation of water supply are being carried out by implementation of ZLD (a significant wastewater management strategy) globally. Application of ZLD systems at industrial scale are limited due to increased energy consumption and their cost even though their capability for minimising water pollution and maximising water resources.

\section{Acknowledgments}

None.

\section{Funding}

None.

\section{Conflicts of interest}

The authors declared that there no conflicts of interest.

\section{References}

1. Rappich $\mathrm{O}$. The rising industrial adoption of zero liquid discharge. Water world; 2016.
2. Yusuf M. Handbook of textile effluent remediation. Pan Stanford Publishing; 2018. $434 \mathrm{p}$.

3. Jordan A. Zero liquid discharge options. Water world; 2009.

4. GPCB. Zero liquid discharge (ZLD) technology guidance manual. 2016.

5. Vishnu G, Palanisamy S, Joseph K. Assessment of field scale zero liquid discharge treatment systems for recovery of water and salt from textile effluents. Journal of Cleaner Production. 2008;16(10):1081-1089.

6. Tong T, Elimelech M. The global rise of zero liquid discharge for wastewater management: drivers, technologies, and future directions. Environmental Science \& Technology. 2016;50:13.

7. Saha I. Zero liquid discharge: treating effluents as a resource stream instead of waste stream is the way forward. 2014.

8. Ahirrao S. Zero Liquid discharge solutions. Industrial wastewater treatment, recycling and reuse. Butterworth-Heinemann; 2014:489-20.

9. Hussain S. Indian case study on ZLD-the tirupur textile cluster experience. 2014.

10. CPCB. Guidelines on techno - economic feasibility of implementation of zero liquid discharge (ZLD) for water polluting industries. India Environment Portal; 2015.

11. Luo L, Jingqi Z, Chung TS. Integration of membrane distillation (MD) and solid hollow fiber cooling crystallization (SHFCC) systems for simultaneous production of water and salt crystals. Membrane Science. 2018;564:905-915.

12. Lu KJ, Zhen LC, Chang J, et al. Design of zero liquid discharge desalination (ZLDD) systems consisting of freeze desalination, membrane distillation, and crystallization powered by green energies. Desalination. 2019;458:66-75

13. Mickley M. Survey of high-recovery and zero liquid discharge technologies for water utilities. WateReuse Foundation; 2008. 